\title{
Velkommen til Tidsskrift for Professionsstudier nr. 24
}

I dette nummer af Tidsskrift for Professionsstudier sætter vi fokus på begreberne 'kultur' og 'civilisering'. Både begreberne hver for sig og forbindelsen mellem dem.

Kulturbegrebet knytter sig ofte til enten kunst og filosofi (et æstetisk kulturbegreb) eller hverdagsliv og livsformer (et antropologisk kulturbegreb), mens civiliseringsbegrebet typisk handler om opdragelsesidealer, normer og selvkontrol. Begreberne er imidlertid langt fra entydige, men har en lang og broget idéhistorie og anvendes samtidig på en lige så lang rækker forskellige måder.

Etymologisk kommer ordet 'kultur' af verbet colere, som i sin latinske oprindelse kan spaltes i to (Fisch 1993: 679-774). På den ene side som cultus, det vil sige, hvor man mere eller mindre tilbedende forholdt sig til det ikke-menneskelige, nemlig guderne. På den anden side som cultura, hvor man dyrkede jorden og i det hele tager plejede og passede alt det menneskeskabte i samfundet - det vi i dag kalder at kultivere. Denne dobbelthed i begrebet colere gjorde, at man befandt sig i en kultur (cultus), men man bevægede sig også i en kultur (cultura). Det vil sige, at kultur var både forudsætning og resultat. At ære guderne og dyrke jorden var to sider af samme sag. I løbet af mid- delalderen og fremefter begyndte de to dimensioner af kulturbegrebet imidlertid at blive adskilt, og fra sidste del af det 18. århundrede etableredes begrebet kultur på tysk i vores betydning, mens begrebet civilisation udviklede sig på fransk og engelsk (Johansen \& Morsing 2014: 7).

Civiliseringsbegrebet er en såkaldt neologisme, der er dannet ud fra det latinske civis, der betyder borger og er afledt af civilis, der har at gøre med det politiske. Det er i den forbindelse bemærkelsesværdigt, at der ikke oprindeligt var et substantiv, som vi i dag kender det med civilisation - det blev først for alvor udbredt at tale om civilisationer $i$ 1700-tallet i forlængelse af oplysningstiden. Men samtidig var netop det med til at udstikke begrebets oprindelige dobbeltbetydning: at der på den ene side er civitas, altså det at være borger i et samfund på højt udviklingsniveau og reguleret af nogle givne betingelser, og på den anden side civilis, altså det man gør - den konkrete politik, der både er afgrænset af byen og begrænset til borgerskabet (ibid.).

I temanummeret vil vi langt fra begrænse os til de oprindelige forståelser af begreberne, men forsøge at komme omkring mange af de forskellige betydninger, som begreberne har fået. Vi tematiserer forskelle og ligheder og analyserer begreberne hver for sig, men også på hvilken måde, de er forbundne indbyrdes. Samtidig undersøger vi, hvordan de to teoretiske begreber kan være relevante for analyser af praksisfeltet - hvilken analytisk kraft har begreberne i forhold til uddannelse, undervisning og pædagogik?

Temanummeret om kultur og civilisering er tilegnet Hans Jørgen Staugaard, som døde i sommeren 2016. Hans Jørgen var i flere år redaktionsmedlem i Tidsskrift for Professionsstudier, hvor han med stort overblik og viden bidrog i planlægningen af kommende tematikker og til analyserne af indkomne artikelforslag, og hvor han samtidig altid var hyggelig, morsom og dejligt diskussionslysten at være sammen med. Han var uddannet cand.mag. i dansk og fransk og ph.d. i uddannelsessociologi og var ansat som lektor og projektleder ved Enheden for Forskning og Udvikling på University College Nordjylland. Hans egen forskning omfattede bl.a. analyser af velfærds- og relationsprofessioner, og han udgav $\mathbf{i}$ den forbindelse en lang række artikler og bøger om professioner og professionsuddannelser. Med Hans Jørgens død har dansk professionsforskning mistet en skarp og begavet skribent og kritiker. I redaktionen har vi mistet en ven. 